\title{
Por Que Pensamento e Não Teoria? A Imaginação Político-Social Brasileira e o Fantasma da Condição Periférica (1880-1970)
}

\section{Christian Edward Cyril Lynch}

Professor e pesquisador do Instituto de Estudos Sociais e Políticos (IESP), da Universidade do Estado do Rio de Janeiro (UERJ), Rio de Janeiro, Brasil

\section{INTRODUÇÃO}

W a última década, a área do chamado pensamento politico-social bra1 sileiro apresentou uma expansão significativa. Ela pode ser medi-
da pelo aumento expressivo do número de dissertações e teses defendidas nos programas de pós-graduação; de comunicações apresentadas nos respectivos grupos de trabalho nos congressos da Associação Nacional de Pós-Graduação em Ciências Sociais (Anpocs), bem como nos encontros da Sociedade Brasileira de Sociologia (SBS) e da Associação Brasileira de Ciência Política (ABCP); de coletâneas de artigos dedicados aos autores canônicos do pensamento brasileiro, como Introdução ao Brasil: um banquete nos trópicos (1999); Nenhum Brasil existepequena enciclopédia (2003); Intérpretes do Brasil - cultura e identidade (2004); e Um enigma chamado Brasil: 29 intérpretes e um país (2009) ${ }^{1}$. Além disso, surgiram novas tentativas de conferir um tratamento teórico mais elaborado a essa área do pensamento político brasileiro, como Linhagens do pensamento político brasileiro, de Gildo Marçal Brandão (2007), e Formação do pensamento político brasileiro, de Francisco Weffort (2006). Ao mesmo tempo, pesquisadores como Marcelo Jasmin e João Feres Júnior procuraram aplicar novas metodologias da teoria política ao pensamento político brasileiro, como a história dos conceitos, de Koselleck, e o contextualismo linguístico da Escola de Cambridge.

DADOS - Revista de Ciências Sociais, Rio de Janeiro, vol. 56, n-4, 2013, pp. 727 a 767. 
Enfim, houve progresso. No entanto, qualquer crescimento de uma área do conhecimento gera crises: emergem novas questões, velhas certezas são alvos de objeções, os consensos começam a sofrer questionamentos, por força do aprofundamento e da especialização dos estudos.

No âmbito das ciências sociais brasileiras, dois projetos de pesquisa servem de referência obrigatória para todos os que se dedicam ao estudo do nosso pensamento político-social; a eles se deve sempre volver, quando se trata de pensar o estatuto da área. O primeiro é aquele de Wanderley Guilherme dos Santos, que fundou o campo de estudos na década de 1970 com textos como Paradigma e história e A práxis liberal no Brasil. Aqui é preciso passar em revista, ainda que sucintamente, suas contribuições à disciplina. Em primeiro lugar, ela produziu um enquadramento disciplinar do objeto. Sua perspectiva epistemológica pragmático-moderada permitiu superar os dilemas até então impostos pelas oposições resultantes, seja do hegelianismo filosófico predominante no Instituto Superior de Estudos Brasileiros (Iseb), seja do positivismo científico esposado pela sociologia da Universidade de São Paulo (USP) em meados dos anos 1950, e que redundavam no desprezo do pensamento brasileiro como periférico ou inferior. Havia uma cultura política nacional; o pensamento político-social brasileiro era, por excelência, o seu produto intelectual, e não era possível compreender o acidentado processo político brasileiro sem estudá-lo. Em segundo lugar, com a pesquisa surgiu uma definição clara do seu estatuto e o seu competente nome de batismo: trata-se de estudar o "pensamento político-social brasileiro" e, em particular, a "imaginação política" nele presente. Em terceiro lugar, delimitou-se o perímetro do pensamento brasileiro no âmbito das ciências sociais. Ao excluir deliberadamente da pesquisa "as obras estritamente históricas, antropológicas, psicológicas, econômicas, metodológicas e escolásticas" (Santos, 2002:14), Wanderley organizou o campo de estudos do pensamento político-social brasileiro no âmbito das ciências sociais ${ }^{2}$. Em quarto lugar, da pesquisa resultava a caracterização do pensamento brasileiro como indissoluvelmente vinculado à prática. Ao contrário da teoria sociológica ou da filosofia, a teoria política está sempre vinculada à prática e, por esse motivo, seu estudo não pode ser eliminado a priori a pretexto de sua dimensão não científica ou ideológica.

O segundo projeto de pesquisa a se reportar para avaliar e se orientar acerca do pensamento político-social brasileiro é o de Gildo Marçal Brandão. O livro Linhagens do pensamento político brasileiro (2007) teve 
por fim fornecer à nova geração uma plataforma intelectual sobre a qual os estudos pudessem avançar. Tratava-se de uma necessidade, que já estaria justificada pela simples falta de qualquer outra tentativa de renovar o estudo da área, trinta anos depois da primeira (embora o projeto de Wanderley esteja ainda longe de esgotar seu potencial teórico). Em suas preocupações, Gildo se revelava interessado em diversas questões, das quais destaco três: a) Podem ser tomadas por equivalentes as categorias criadas pelos acadêmicos para designar as duas principais "linhagens" da tradição política brasileira (a "liberal" e a "conservadora")? Oliveira Viana falava em idealistas orgânicos e utópicos; Guerreiro Ramos, em críticos e ingênuos; Wanderley Guilherme, em autoritários instrumentais e liberais doutrinários; Werneck Vianna, em iberistas e americanistas; b) A caracterização conferida por tais acadêmicos a cada uma daquelas linhagens não espelharia suas próprias filiações ideológicas a alguma delas? Ou seja, em que medida as denominações e descrições conferidas por cada um deles àquelas linhagens não reflete a preferência de seus autores a uma ou outra?; c) Poderia uma reconstrução adequada da trajetória daquelas linhagens, a partir de suas respectivas matrizes ideológicas, servir de instrumental interpretativo do campo político-partidário brasileiro, de forma a compreender a história política brasileira? Em outras palavras, a luta política atual, travada principalmente por dois partidos - os tucanos e os petistas - não representaria, de algum modo, a sobrevivência daquelas linhagens na atualidade? ${ }^{3}$ Infelizmente, a morte inopinada de Gildo, poucos meses depois de inaugurado o debate público sobre o seu projeto, na Universidade de São Paulo, nos privou da possibilidade de vir a ouvi-lo, nos anos que se seguiram, não somente sobre essas questões, mas sobre tantas outras, que certamente surgiriam no caminho.

Para tornar a perspectiva ainda mais incerta, havia uma série de perguntas ou problemas que, a meu juízo, deveriam ser enfrentados antes de se lançar ao desafio de responder às questões antes referidas. Um dos maiores obstáculos ao desenvolvimento consistente da disciplina nos dias atuais reside, a meu ver, na falta de uma reflexão metateórica sobre o seu estatuto, que deveria passar por uma discussão dos fundamentos sobre os quais a disciplina se encontra ancorada. Não são apenas os problemas metodológicos que não são discutidos ou explicitados; as próprias categorias e conceitos da disciplina parecem ocultar problemáticas de grande envergadura. Por exemplo: empregam-se as expressões história das ideias e pensamento indistintamente, para denominá-la. Mas o conceito de pensamento mantém tensas relações com os 
de ideologia, teoria ou ciência. Por que se empregam essas diferentes expressões? São sinônimas? Ou querem dizer coisas diferentes? Coabitam em extraordinária polissemia designações como pensamento social, pensamento político, pensamento social e político e pensamento político-social, às vezes como sinônimos, às vezes como antônimos, sem que se saiba sua abrangência ou seu significado. Outra questão: por que alguns preferem dizer que a disciplina é de pensamento no Brasil e não de pensamento brasileiro? Há diferença? Caso positivo, quais são os critérios que orientam essas escolhas? Permanecem válidos? Em suma, os pressupostos que têm orientado as pesquisas permanecem implícitos, naturalizados. Não será hora de revistar essas questões, a fim de avançar a pesquisa da área e firmá-la em solo menos vacilante?

Para dar conta desses problemas, seria preciso desenvolver um projeto voltado para a apreensão do próprio processo histórico, conceitual e intelectual de gestação desse campo de estudos, capaz de oferecer um primeiro balanço sobre o processo de formação da disciplina. Uma reflexão de cunho metateórico, na forma de uma história da história do pensamento político-social brasileiro, permitiria romper com o naturalismo que predomina nos estudos da área, identificar os eventuais problemas existentes e apontar os meios para sua resolução. Em princípio, esse projeto se organizaria em torno de questões como as seguintes: a) Como a filosofia, a história e as ciências sociais europeias pensaram a natureza e a finalidade de uma história das ideias ou de uma história intelectual?; b) De que maneira a intelectualidade ibero-americana recepcionou, pensou e praticou esse gênero? Como os intelectuais brasileiros lidaram com o objeto, antes da institucionalização das ciências sociais?; c) De que maneira se deu a institucionalização acadêmica do pensamento político brasileiro ou da história das ideias políticas brasileiras no âmbito das ciências sociais? O modo diverso por que ela foi institucionalizada em diferentes centros acadêmicos não se reflete igualmente nos diferentes modos por que ela é ainda hoje compreendida?; d) Qual o estado atual da arte? Ele induz a pensar em continuidades ou em rupturas? Quais as suas tendências atuais?

Este artigo representa uma tentativa de começar a responder a tais questões. Ele tenta compreender, em primeiro lugar, por que chamamos à reflexão política brasileira pensamento e não teoria. A hipótese que pretendo aqui explorar é a de que, no Brasil, suas elites sempre consideraram seus produtos intelectuais mais ou menos inferiores àqueles desenvolvidos na Europa e nos Estados Unidos, em conse- 
quência de uma percepção mais ampla do caráter periférico do seu país. Na primeira seção deste artigo, para contextualizar a hipótese aventada, discutirei a questão terminológica entre "teoria" e "pensamento" no âmbito da ciência política. Por pensamento político, entendo aqui uma gama de manifestações mais amplas que aquelas de cunho estritamente jurídico-constitucional; e que se refere ao domínio do político entendido como poder, e que incorpora, na análise, o seu entorno "social" (Santos, 1970:137). Sempre provocado pelas reflexões de Marcelo Gantus Jasmin (especialmente depois de ouvir sua conferência Limites da história universal ${ }^{4}$, aplicarei à história do pensamento político-social brasileiro, entendido como periférico, as consequências da hegemonia, durante o seu primeiro século e meio de existência, de um regime eurocêntrico e evolucionista de historicidade, tal como descrita por historiadores como Reinhart Koselleck, François Hartog e Hans Georg Gumbrecht, e hoje em estágio final de superação. Parto da suposição de que aquela hegemonia, entendida como uma moldura intelectual ampla a partir da qual eram pensadas as condições de existência da comunidade política, permite compreender por que nossos autores não reconheciam a dignidade da produção intelectual, levando-os a ignorá-la ou a menosprezá-la.

Em seguida, examinarei como alguns dos nossos principais intérpretes avaliaram o lugar do Brasil no mundo e a qualidade de seus produtos intelectuais, especialmente os de natureza social e política. Esse exame será dividido em duas partes. Na primeira, que corresponde ao que chamo hegemonia do paradigma cosmopolita periférico (1880-1930), selecionei os intelectuais através de um critério institucional, focando naqueles que ocupavam a Academia Brasileira de Letras (ABL) e o Instituto Histórico e Geográfico Brasileiro (IHGB). Tal escolha não me impediu, porém, de recorrer também ao testemunho de intelectuais de outras instituições, como as Faculdades de Direito, a Politécnica e o Colégio de Dom Pedro II. Na segunda parte, que corresponde ao período que chamo do paradigma nacionalista periférico (1930-1970), centrei a atenção nas três instituições que mais se destacaram no estudo do pensamento brasileiro: o Instituto Brasileiro de Filosofia (IBF), o Instituto Superior de Estudos Brasileiros (Iseb) e a Faculdade de Filosofia, Letras e Ciências Humanas da Universidade de São Paulo (FFLCH-USP). No final, espero ter podido oferecer um panorama preliminar do pensamento político brasileiro, assombrado pelo "fantasma da condição periférica" - até a década de 1970, quando a pesquisa de Wanderley Guilherme dos Santos no antigo Instituto Universitário 
de Pesquisas do Rio de Janeiro - Iuperj (atual Instituto de Estudos Sociais e Políticos - Iesp-Uerj) constituiu o campo de estudos homônimo e difundiu na ciência social a expressão por que veio a ser conhecido: pensamento político-social brasileiro.

\section{POR QUE PENSAMENTO E NÃO TEORIA POLÍTICA BRASILEIRA?}

A palavra "teoria" costuma ser empregada para designar um conjunto de proposições lógico-abstratas que descrevem as leis de funcionamento de um determinado fenômeno. Não é por outro motivo que, nas ciências humanas, as grades curriculares do ensino superior estão repletas de disciplinas de "teorias" alusivas a ramos do conhecimento como filosofia, direito, sociologia, antropologia, economia, administração, história etc. Na ciência política, temos teoria política. Por emulação do método autoral empregado pela filosofia, o ensino de tal disciplina é ministrado pela leitura sucessiva das obras dos autores julgados "clássicos" daquela área em virtude de contribuições julgadas fundamentais por aqueles que a ensinam. Assim, os estudantes de política não escapam à leitura de Maquiavel, Hobbes, Locke, Montesquieu, Rousseau, Tocqueville, Marx, Mosca, Michels, Carl Schmitt, ou Schumpeter. Mais adiante, o estudante pode vir a encontrar outra disciplina, por que tomará contato com as principais obras políticas produzidas no Brasil. Essa disciplina parece o equivalente nacional daquela de teoria política e é ministrada da mesma forma, pela apresentação dos "grandes livros" dos nossos "clássicos", como o visconde de Uruguai, Tavares Bastos, Joaquim Nabuco, Rui Barbosa, Alberto Torres, Oliveira Viana, Sérgio Buarque, Raimundo Faoro etc. Ela se chama pensamento político-social brasileiro, pensamento social e político brasileiro ou simplesmente pensamento político brasileiro.

Diante dessas informações, a primeira pergunta que vem à cabeça do estudante é: por que esta última recebe uma denominação diferente? Por que aquela se chama "teoria" e esta se chama "pensamento"? A resposta não é simples. Poucos autores explicitam os motivos de terem escolhido esta ou aquela denominação. Em princípio, pode-se conjecturar não haver qualquer motivo especial em se distinguir o nome de uma disciplina da outra; é possível argumentar que, na verdade, não houve nenhum propósito de distingui-las: teoria ou pensamento seriam expressões intercambiáveis ${ }^{5}$.

Há, porém, uma primeira justificativa para diferenciar teoria ou filosofia política, de um lado, de pensamento ou história das ideias políticas, 
de outro. Os textos "teóricos" ou "filosóficos" seriam coerentes, abrangentes e abstratos, ao passo que aqueles sob a rubrica "pensamento" seriam fragmentários, contingentes ou assistemáticos. No campo dos estudos políticos, foi Leo Strauss quem esclareceu as diferenças entre filosofia política e pensamento político. Se a filosofia pura se caracterizava pela busca da sabedoria e do conhecimento do verdadeiro e do universal, a filosofia política consistia na tentativa de se orientar, não pela opinião, mas pelo ideal da ordem política justa. Composta de um conjunto de reflexões elaboradas por autores desapaixonados e contemplativos, dialogando com a tradição filosófica clássica, a filosofia política tinha por fim discutir as "questões perenes da humanidade" e tinha por veículos longos, densos e sistemáticos tratados (Strauss, Cropsey, 1996:11). A filosofia política se distinguia do "pensamento político em geral" na medida em que este último estava voltado para a prática e, por conseguinte, não tinha o mesmo rigor, a mesma coerência, a mesma universalidade. O pensamento político se manifestava por meio de leis, códigos, poemas e histórias das ideias, panfletos e discursos públicos. Seria assim possível fazer, alternativamente, ou "história da filosofia", ou "história das ideias", dependendo da qualidade do material estudado: filosofia política, no primeiro caso, pensamento político, no segundo. Ali se achariam autores como Platão, Aristóteles, Locke, Hobbes, Hume, Montesquieu; aqui, outros, como Sieyès, Jefferson, Constant, Guizot ou Macauley ${ }^{6}$.

Para além dessa primeira explicação, pode-se avançar uma segunda para justificar a diferença entre filosofia e teoria (e, por conseguinte, história da filosofia ou da teoria), de um lado, e "pensamento" (ou história das ideias ou do pensamento), de outro. A palavra filosofia ou teoria seria empregada para designar o conjunto de textos de natureza política de validade universal, ao passo que pensamento político ou história das ideias nomearia aqueles de validade apenas nacional. O próprio Isaiah Berlin se referia sem constrangimentos a uma "filosofia inglesa"; a uma "história do pensamento político inglês"; a uma "história intelectual americana", objeto de uma cadeira específica nas universidades estadunidenses (Jahanbegloo, 1996: 123). Poderíamos, assim, falar num pensamento político britânico, que, para além de autores "universais" como Locke, Hobbes, Burke, Bentham, Mill e Spencer, contaria com autores de menor estatura, mas relevantes no contexto nacional daquele país, como Macauley, Brougham, T.H. Green, Hobson e Hobhouse. Poder-se-ia pensar, por idêntico, num pensamento político francês, que, para além de autores "clássicos" como Bodin, Bossuet, Montesquieu, 
Rousseau, Constant e Tocqueville, contasse também com outros, "menores", como Sieyes, Guizot, Laboulaye, Taine ou Barrès. Seguindo esse raciocínio, para além dos autores de vocação "universal", integrariam o cânone do "pensamento político nacional" autores "menores", que, no entanto, teriam repercutido na vida intelectual do país. De fato, na Espanha e na Argentina fala-se em "pensamento político espanhol" e "pensamento político argentino"7. Conciliar-se-iam assim a dimensão universalista da teoria política ou da filosofia, de um lado, com o seu reflexo nacional particular, de outro, designado este como pensamento ou história das ideias políticas. Em síntese: o "pensamento político" seria a "teoria política" em contexto nacional.

Por mais que essas explicações sejam válidas para justificar a diferença no emprego das expressões teoria e pensamento no Brasil, creio que, além delas, há uma terceira: a percepção difusa do tempo (atrasado) em que o país se encontraria, decorrente do lugar (periférico) por eles ocupado no mundo. Essa percepção secular, por parte das elites ibero-americanas, de se acharem excluídas de um "centro" do mundo, mais importante e superior, localizado no Atlântico Norte, repercutiu diretamente na definição de suas identidades nacionais depois da independência.

A internalização desta condição de inferioridade, na forma de um sentimento de exclusão do "mundo civilizado", ou de sua inserção nele numa condição subalterna, se refletiu no pouco caso demostrado pelas elites dos países periféricos ao pensamento produzido por elas mesmas, comparado àquelas elaboradas nos países centrais. Dependentes dos modelos culturais dos países cêntricos, que distribuíam os lugares e os papéis das nações no mundo, elas internalizaram o pressuposto de sua inferioridade neles inscrito. As diferenças quantitativas entre as nações do "centro" e da "periferia", medidas objetivamente em termos de tecnologia ou poder militar, se converteram em diferenças qualitativas no plano da existência: aquilo que era apenas um juízo de fato (assimetria militar e econômica) se transformou, no plano das representações sociais, num juízo de valor (inferioridade no plano da existência e da cultura). Os europeus e norte-americanos seriam "adiantados", "desenvolvidos", "civilizados", "primeiro mundo", ao passo que os ibero-americanos eram "atrasados"; "subdesenvolvidos"; "bárbaros" ou "semibárbaros". Era como se prevalecesse uma divisão internacional do trabalho intelectual: na geografia do mundo, o "centro", o "lugar" produzia o "universal" (filosofia, teoria, ciência); ao passo que ca- 
bia à periferia aplicá-lo às suas circunstâncias particulares. Esse processo por que os autores periféricos "aplicavam" a teoria cêntrica dava origem a um tipo de reflexão menor, espécie de rescaldo da anterior: precário, fragmentário, contingente ou assistemático, válido somente dentro de seus próprios limites (nacionais). Em outras palavras, por meio daquele processo de "aplicação", a periferia se tornava por excelência o lugar onde se concentravam todas as características do pensamento descritas nas explicações anteriores.

Nas décadas que se seguiram à independência das nações do subcontinente, uma matriz histórico-filosófica se destacou no papel de estabelecer distinções qualitativas entre uma teoria cêntrica, valorada como universal e original, e um pensamento periférico, avaliado como local, bárbaro, ou copiado, ou deformado. Trata-se da filosofia da história ou cronosofia, bosquejada na Europa ocidental na passagem do século XVIII para o seguinte, e renovada, em diferentes versões, como "uma interpretação sistemática da história universal de acordo com um princípio segundo o qual os acontecimentos e sucessões históricos se unificam e dirigem para um sentido final" situado no futuro (Löwith, 1977: 15). Pressupondo a falta de identidade da natureza humana no tempo, entendida, agora, não mais como constante, mas perfectível ou mutável, o passado não ensinava mais o presente, que lhe era intrinsecamente diferente; sua utilidade estava tão somente em fornecer ao filósofo material para que ele pudesse compreender as leis por que se sucediam os estádios do processo histórico. Assimilada como um esquema de ordem e sentido progressivos, organizador dos lugares das diversas nações ao longo do tempo, a filosofia da história recebeu diversas versões, sendo as mais conhecidas as de Condorcet, Hegel, Comte, Spencer e Marx. Todas tentavam explicar o papel dos diversos povos e a função de suas ideias ou de sua cultura naquele processo. Todas pressupunham que, orientadas por um telos futuro de paz, de liberdade e igualdade "universais", havia nações que marchavam à frente, e outras, atrás, conforme critérios como maior ou menor esclarecimento (isto é, difusão das "luzes", da "razão", do conhecimento), e/ou maior ou menor desenvolvimento material (quase sempre entendido como industrial). As primeiras pertenciam ao "centro"; as segundas, à sua periferia. As nações "cêntricas" o eram porque estavam mais próximas de atingir aquele telos; do ponto de vista da sua temporalidade, eram julgadas como situadas no "presente" e, como tal, eram "normais". As demais nações, "periféricas", se achavam numa etapa mais recuada e, como tal, distante do "futuro", estando, enquanto tais, "atrasadas"; 
elas se encontravam de alguma maneira no "passado" das nações cêntricas, vivenciando etapas que aquelas já tinham vencido. As nações periféricas estavam, assim, aos olhos do centro, numa condição "atrasada" e "anormal". Terra do exótico, a presunção era a de que nenhum produto cultural que viesse delas pudesse contribuir para o avanço da civilização, já que ela se encontrava no passado dos países cêntricos.

Assim, por exemplo, a versão liberal da filosofia da história, elaborada por Condorcet e aperfeiçoada por Constant, compreendia a articulação da temporalidade como um quadro das sucessivas etapas por que progredia o "espírito humano". O conhecimento do processo histórico permitia constatar o aperfeiçoamento do homem ao longo da história, que redundaria num futuro de absoluta liberdade e igualdade entre indivíduos e nações. Em virtude da "superioridade de suas luzes e as vantagens de seu comércio", esse progresso era produzido nos países europeus e se disseminava sobre o seu entorno: América, África e Ásia (Condorcet, 1993:179). Os povos periféricos esperavam "instruções para se civilizar e encontrar irmãos nos europeus, para tornarem-se seus amigos e seus discípulos" (Idem:180). Nessas regiões, o progresso seria mais veloz, já que todas as atitudes, comportamentos e princípios "modernos" já a elas acorreriam prontos, explicados pelos livros europeus que civilizariam o resto do mundo. No Novo Mundo, caberia à população de origem europeia "civilizar ou fazer desaparecer, mesmo sem conquista, as nações selvagens que ali ainda ocupam vastas regiões" (Idem:178). Na África e na Ásia, os emigrados europeus difundiriam, pelos povos selvagens e pelas civilizações decadentes que as habitavam, "os princípios e o exemplo da liberdade, as luzes e a razão da Europa" (Idem:179). Por sua vez, Hegel elaborou uma cronosofia descritiva das sucessivas etapas do progresso do Espírito que conduzia o homem rumo à liberdade e desvelava a razão de Deus na história. Essa cronosofia deu origem a uma história da filosofia na qual cada etapa daquele processo de desenvolvimento do espírito poderia ser intelectualmente apreendida pelo conteúdo das obras deixadas pelos grandes homens ou gênios de cada povo. Eram elas que revelavam a existência daquela razão divina, exterior à vida humana, na forma de uma ideia que possuía, igualmente, uma "essência" acima das contingências da história. O papel da história da filosofia era, portanto, o de conhecer as grandes obras e, por intermédio delas, as ideias dos gênios das diversas nações, cuja originalidade desvelava em perspectiva universal a marcha do espírito humano. 
A história da filosofia expõe-nos a galeria dos nobres espíritos que, graças à ousadia da sua razão, penetraram na natureza das coisas do homem, e na natureza de Deus, desvelaram-nos a sua profundidade e para nós elaboraram o tesouro do mais alto conhecimento. Semelhante tesouro, de que nós próprios queremos partilhar, constitui a filosofia em geral; a origem de tal tesouro é o que neste curso aprendemos a conhecer e a captar (Hegel, 2006:13).

O problema é que, do ponto de vista geográfico, o surgimento desses grandes homens não se dava, nem aleatória, nem democraticamente. Embora a marcha do Espírito fosse universal, ele somente se manifestava naqueles povos mais antigos e de cultura mais adiantada; só neles havia condições de se produzir pensamento original, ou seja, filosofia. Para piorar, Hegel entendia que o Novo Mundo, por muito tempo, não teria possibilidade de produzir uma filosofia de verdade, original. Desabitado, ou parcialmente habitado por populações transplantadas de outras regiões, que delas traziam as suas experiências, o Novo Mundo era um continente que não deixava, é certo, de ter uma especificação própria. Mas, do ponto de vista do verdadeiro conhecimento, a América só podia exprimir sonhos e aspirações futuras, não presentes. Ainda às voltas com o controle da natureza, que dizia respeito antes à questão da necessidade do que à da liberdade, os países americanos não tinham como figurar tão cedo no plano da história universal. Na América, "as meditações sobre o passado não se expressavam em filosofia da história do mundo", ou seja, como "reflexão sobre o ser do homem com entrada na ontologia". A América Ibérica não produzia filosofia, mas pensamento; não filósofos, mas pensadores encarregados de redigir "ensaios pedagógicos, políticos ou sociais" (Zea, 1956:106). Criava-se, assim, um circuito fechado que a prisionava a reflexão dotada de sistematicidade, originalidade e profundidade nos limites dos países "cêntri$\cos ^{\prime \prime}$, excluindo a possibilidade de sua existência na periferia.

Por isso, ao inventariarem o que seus países produziram de relevante no campo da reflexão, os intelectuais periféricos não poderiam acreditar que aquilo pudesse ser considerado parte integrante da "história da filosofia". O máximo a que se poderiam permitir era acreditar que o inventário da produção intelectual nacional pudesse ser descrito no plano de uma "história de ideias" , marcada pela sua dimensão prática, pela sua contingência e pela sua validade limitada ao plano do local. Não é inútil recordar aqui o modo por que Hegel se referia às histórias das ideias: elas eram "o magote das opiniões filosóficas", a "galeria 
das tolices ou, pelo menos, dos desvios do homem que se absorveu no pensar e nos simples conceitos" (Hegel, 2006:113). A partir de semelhantes noções hauridas de cronosofias eurocêntricas, os países ibero-americanos formularam a imagem que longamente guardariam de si mesmos, e que, na sua versão mais negativa, os apresentava como culturalmente exóticos, historicamente atrasados e racialmente inferiores.

Ao mesmo tempo, identificadas com os valores "civilizados" europeus, suas elites "crioulas" se viam como "administradoras" de uma realidade em tudo diferente daquela do Velho Mundo, que lhes era culturalmente familiar. Enquanto a condição política colonial durou, essas elites se consideravam sentinelas avançadas da "civilização" cêntrica na periferia. Depois da independência, alguns intelectuais periféricos perceberam-nas como um momento de queda, que os desligara do "universal" para exilá-los na América ${ }^{8}$. Os intelectuais pertencentes às elites periféricas passaram então a vivenciar o "dilema do mazombo", entendido como o "descendente de europeu ou reputado tal, com um pé na América e outro na Europa, e equivocadamente persuadido de que, cedo ou tarde, terá de fazer uma opção" (Mello, 2002:368). Entre nós, foi Joaquim Nabuco quem, em 1900, fez a clássica descrição do dilema do mazombo, fraturado entre uma jovem pátria "geográfica", periférica, lugar do sentimento e da natureza (o Brasil), e uma antiga pátria "espiritual", cêntrica, lugar da inteligência e da civilização (a Europa). Segundo ele afirmava em Minha formação, todos os povos do Novo Mundo pertenciam "à América pelo sedimento novo, flutuante, do nosso espírito, e à Europa, por suas camadas estratificadas". Este duplo pertencimento, todavia, não se dava de forma igualitária: "Desde que temos a menor cultura, começa o predomínio destas sobre aquele". O resultado era que, no Novo Mundo, as elites culturais ficavam condenadas "a mais terrível das instabilidades", o que explicava "o fato de tantos sul-americanos preferirem viver na Europa. É a atração de afinidades esquecidas, mas não apagadas, que estão em todos nós, da nossa comum origem europeia". E prosseguia:

A instabilidade a que me refiro provém de que na América falta à paisagem, à vida, ao horizonte, à arquitetura, a tudo o que nos cerca, o fundo histórico, a perspectiva humana; e que na Europa nos falta a Pátria, isto é, a forma em que cada um de nós foi vazado ao nascer. De um lado do mar sente-se a ausência do mundo; do outro, a ausência do País. O sen- 
timento em nós é brasileiro, a imaginação é europeia (Nabuco, 1949b:47-48).

A imagem do brasileiro culto sentindo-se expatriado no próprio país, alheio à própria cultura da população local, seria formulada em 1922 por Lima Barreto, em Transatlantismo: “Nós, brasileiros, somos como Robinsons: estamos sempre à espera do navio que nos venha buscar da ilha a que um naufrágio nos atirou" (Barreto, 1922). Em 1932, em Brasil errado, Martins de Almeida diria: "O brasileiro é um exilado dentro da própria terra" (Almeida, 1932:53). Quatro anos depois, Sérgio Buarque de Holanda se limitaria a repetir a fórmula de Almeida, em Raízes do Brasil: "Somos ainda uns desterrados em nossa terra" (Holanda, 1936:3).

\section{O PENSAMENTO BRASILEIRO SOB O SIGNO DO COSMOPOLITISMO PERIFÉRICO (1880-1930)}

Exposta esta hipótese - a de que a percepção periférica das elites ibero-americanas se refletiu num sentimento de inferioridade a respeito de seus produtos culturais -, gostaria de me deter no caso brasileiro. Ao longo de nossa história intelectual, manifestou-se esse sentimento de inferioridade entre nós? Para responder a essa pergunta, é preciso recuperar os pressupostos da filosofia da história que especificavam as condições para a existência de uma cultura nacional.

Até o final da Primeira Grande Guerra, a intelectualidade ibero-americana vivia sob o influxo de um paradigma civilizacional liberal, cosmopolita, para o qual havia um processo unilinear de civilização que, partindo da Europa, se espalhava pela periferia dela. Fenômeno europeu, a civilização poderia ser difundida para a periferia pelas armas, pela economia e pela cultura. Na França, as linhas gerais da filosofia da história de Hegel foram absorvidas por intelectuais como Victor Cousin, Renan e Taine'. Daí a utilidade de a elas recorrer aqui. Para Cousin, "as ideias diversas representadas pelos diversos povos" eram os objetos centrais de uma história universal ou filosófica (In: Gauchet, 2002:191). Os povos eram os grandes sujeitos da história. Mas um "povo verdadeiro" não se confundia com mera população; ele tinha um "espírito", na forma de uma cultura própria, que o habilitava a contribuir para o processo civilizador e se projetar no plano da história universal: "Um povo não é somente uma coleção mais ou menos considerável de indivíduos reunidos acidentalmente pelo vínculo de uma força externa preponderante", explicava ele na sua Introdução à Histó- 
ria da Filosofia. "Um povo só é um verdadeiro povo se exprimir uma ideia que, passando por todos os elementos de que é composta a vida interior de um povo, na sua língua, na sua religião, nos seus costumes, nas suas artes, nas suas leis, na sua filosofia, dá a esse povo um caráter comum, uma fisionomia distinta na história". O "espírito do povo" era definido como "o princípio de desenvolvimento e de ação, é uma força da qual o povo extrai a sua, que o move e o sustenta enquanto ele dura, e que, quando ele se retira, depois que o seu desenvolvimento está completo e esgotado, o abandona e o entrega ao primeiro conquistador" (Idem: 261-262). Esse "espírito do povo", entendido como sua cultura própria, original, se manifestava nas obras dos "grandes homens" que formavam sua elite social, política, militar, artística (Idem:263). Bastava reunir os grandes homens fornecidos pelos diversos povos ao longo do tempo, e o estudioso teria diante de si a história inteira, a ordem universal (Idem:266). A filosofia, por seu turno, era considerada a atividade mais elevada por que um grande homem poderia exprimir aquele "espírito". Haja vista que "o degrau mais elevado da individualidade é necessariamente a reflexão", a filosofia era "o último degrau e o resumo necessário do desenvolvimento de um povo" (Idem:261-262).

As elites oitocentistas brasileiras cedo absorveram esses conceitos e categorias, extraídos da filosofia da história, e a cultivaram por muito tempo Assim, por exemplo, em 1919, em sua História da civilização, Oliveira Lima ainda ensinava: "A história da civilização é, em resumo, a história da luta da liberdade contra o despotismo, e da igualdade contra o privilégio"; ela se desdobrava na forma de um "progresso humano constante: mesmo quando se dá recuo, é para melhor avançar" (Lima, 1967:29). Para ele, era "a contribuição para o progresso comum" que emprestava, "a uma raça qualquer, foros de civilizada" (Idem:16). O mundo era composto de três raças: a branca oferecia "o espetáculo de um progresso contínuo e compreensivo"; a amarela, longamente estacionária, dava sinais de querer se adiantar; já a negra se mostrava "ainda hoje refratária a uma civilização regular e progressiva" (Idem:24-25). Essa concepção etnocêntrica de ordem internacional se estendia à concepção que os países cêntricos faziam do lugar de cada país independente na ordem internacional, que transpareceu em 1907 na proposta britânica para a composição do tribunal internacional arbitral planejado por ocasião da Segunda Conferência de Haia. Os países de primeira linha, que dariam um juiz cada, eram: França, Inglaterra, Áustria, Alemanha, Itália, Rússia, Estados Unidos, Japão e Holan- 
da. Os de segunda classe, que, agrupados, dariam cada qual um juiz, eram: Espanha e Portugal; Bélgica, Suíça e Luxemburgo; Turquia e Pérsia; China e Sião; Suécia, Noruega e Dinamarca. Os países de terceira ordem tinham suas individualidades totalmente dissolvidas: eram aqueles situados nos Bálcãs; na América Central e México, e na América do Sul; cada subcontinente daria um juiz cada. Por esse critério, podem ser vistos quais eram o lugar e o peso do Brasil na ordem mundial: estava na extrema periferia dos países independentes; valia tanto quanto a Sérvia e menos do que protetorados asiáticos, como o Sião e a Pérsia (Laidler, 2010:146).

No entanto, como nossos intelectuais situavam ou percebiam o Brasil a partir desse quadro da história universal entendida como um processo de civilização? Eles por certo não duvidavam de que houvesse aqui um Estado; do que eles não estavam certos era que houvesse aqui um povo como aquele descrito por Cousin, distinto de uma mera população. Percepções como esta podem ser encontradas em intelectuais atuantes nas principais instituições intelectuais do país entre 1880 e 1930: o Instituto Histórico e Geográfico Brasileiro (IHGB), a Academia Brasileira de Letras (ABL) e o Colégio de Dom Pedro II (CPII), em primeiro lugar, mas também noutras, como as Faculdades de Direito, a Escola Politécnica e o Pedadogium (instituição encarregada de balizar o ensino médio dos Estados federação). Assim, o professor da Escola Politécnica do Rio, Louis Couty, declarava em A escravidão no Brasil (1881): “O Brasil não tem povo" (Couty, 1988:102). Em 1905, o diretor do Pedagogium, Manuel Bonfim, declarava em América Latina: males de origem: "Pouco importa o que está escrito nas Constituições, que as camadas políticas vão depositando nos armários oficiais. Como estamos, não somos nem nações, nem repúblicas, nem democracias" (Bonfim, 1993:331). Em 1889, o deputado Joaquim Nabuco (futuro membro da ABL e do IHGB) explicava por que ainda não teria chegado a hora de substituir a monarquia pela república: "É que ainda não temos povo" (Nabuco, 1949a:373). Para Oliveira Lima (também IHGB e ABL), havia uma diferença entre povo, que supunha unidade de raça, e nacionalidade, que exigia apenas unidade de Estado (Lima, 1967:21). Coerente com essa distinção, ele batizou o livro que reuniu suas conferências sobre a história brasileira na Sorbonne de Formação histórica da nacionalidade brasileira (1911). Em 1914, Alberto Torres (IHGB) ia mais longe: "Este Estado não é uma nacionalidade; este país não é a uma sociedade; esta gente não é um povo. Nossos homens não são cidadãos, não são pessoas, não são valores" (Torres, 1982a:199). Em 1916, era a vez de 
Gilberto Amado (futuro membro da ABL) declará-lo, da tribuna da Câmara dos Deputados: "Povo propriamente não o temos. Sem contar o das cidades, que não se pode dizer seja uma população culta, a população politicamente não têm existência" (Anais, 11/12/1916).

Ora, no esquema da filosofia hegemônica da história, o povo era o protagonista da história universal. Se não havia povo brasileiro, não havia cultura brasileira; e, sem ela, o país não participava da "história universal". Considerando sua localização americana, sua composição populacional e o seu caráter de país novo, o Brasil não podia ter história no sentido universal. Não houvera ainda tempo para que a ação do homem de origem europeia trabalhasse a natureza para transformá-la em cultura. O Brasil ainda não tinha história, mas geografia; ainda não tinha povo, permanecendo tão somente um país (i.e., território). Essa imagem do Brasil como reduzido à condição de natureza e geografia, privado de cultura e excluído da civilização, perpassava os testemunhos dos principais intelectuais da nossa belle époque. Em Minha formação (1900), o sobredito Nabuco escrevia: "O espírito humano, que é um só e terrivelmente centralista, está do outro lado do Atlântico; o Novo Mundo para tudo o que é imaginação estética ou histórica é uma verdadeira solidão" (Nabuco, 1949b: 48). Em Contrastes e confrontos (1907), afirmava Euclides da Cunha (ABL, IHGB e CPII): “Não temos ainda uma história. Temos anais, como os chineses. A nossa história, reduzida aos múltiplos sucessos da existência político-administrativa, falta inteiramente a pintura sugestiva dos homens e das coisas, ou os travamentos de relações e costumes que são a imprimidura indispensável ao desenho dos acontecimentos" (Cunha, 1975:161). Não fossem uns poucos "fatos, episódios empolgantes e alguns atores esculturais", de que a nossa pequena curta política era feita, seria possível estender para o conjunto do Brasil a expressão por que, havia pouco, Euclides designara a Amazônia: tratava-se de uma "terra sem história" (Cunha, 1999). Em A organização nacional (1914), Alberto Torres volvia à carga: "O destino de um país é função de sua história e de sua geografia. O Brasil não tem história, que tal nome não merece a série cronológica dos fastos das colônias dispersas, e a sucessão, meramente política, de episódios militares e governamentais" (Torres, 1982a:64).

Mas os efeitos devastadores da condição periférica à luz da filosofia da história oitocentista não paravam por aí. Se o Brasil não tinha povo nem cultura, também não tinha grandes homens. Era de que se lamentava em 1910 o jovem Gilberto Amado, em A chave de Salomão: "Não ti- 
vemos ainda um grande homem. Temos tido apenas pedaços de grandes homens. No desenlace de uma história de quatro séculos, não tivemos ainda um pensador". Quando apareciam os candidatos ao posto, eles rapidamente se desfaziam "numa coruscação de insetos efêmeros" (Amado, 1963:16). Daí o deserto de ideias e ideais; a vacuidade da vida intelectual no Brasil. "Quase ninguém se ocupa de ideias gerais", prosseguia Amado. "Nós somos vinte e cinco milhões, e não chega a uma dezena o número de homens capazes de se apaixonarem por uma ideia pura, por um pensamento desinteressado" (Idem:17). Num ambiente como esse, em todo adverso, era trágica a vida daqueles que, na América do Sul, pretendiam dedicar-se ao pensamento:

Todos nós sabemos do horror que é o destino do intelectual, do pensador de nascença no Brasil (...). A sua solidão é a mais patética do mundo. Não tem eco no seio dos seus contemporâneos. É um inútil. (...). Quando ele se lembra de que não terá eco no ambiente em que vive, nem fora dele, e se lembra de que nunca poderá intervir na corrente do pensamento universal, o seu desgosto pode ser ingênuo, para os gozadores e superficiais, mas é profundamente trágico. Nunca o seu pensamento será um fato capital do espírito humano, e a sua ambição intelectual terá de restringir-se aos papéis secundários, aos arremedos, aos comentários (Idem:15).

Esse sentimento de exclusão do Brasil da "história universal", que devia procurar o tanto quanto possível imitar a "civilização" para diminuir a distância em relação a ela, se traduziu na produção de uns poucos e incompletos inventários de sua história intelectual até a Primeira Guerra Mundial ${ }^{10}$. Sem história, sem cultura, sem povo, sem grandes homens, não havia pensamento intelectual digno de ser inventariado. Poderiam ser redigidas "histórias do Brasil" de natureza pragmática, descritivas dos acontecimentos políticos, econômicos e sociais ocorridos no país. Também poderiam ser produzidos trabalhos de utilidade para a realidade local ou consumo de suas elites, a partir dos modelos europeus. Mas nada disso tinha importância para a história do mundo. Essa sensação periférica teve repercussões na forma por que o "mazombo" avaliava suas atividades intelectuais no Novo Mundo. Se os frutos de sua atividade intelectual lhe pareciam sempre brilhantes, quando comparados àquele da população autóctone, vista como inferior e primitiva, por outro lado, eles lhe pareciam sempre de escasso valor, quando comparados àqueles oriundos dos países cêntricos, que lhe serviam de modelo. Os exemplos a seguir ilustram uma tendência persistente de se avaliar negativamente a produção intelectual brasi- 
leira, por parte daqueles que se dedicavam a inventariá-la, desde o final do Império até a Primeira Guerra Mundial.

Em A filosofia no Brasil (1886), Sílvio Romero (futuro fundador da ABL) foi terminante: "Este país não tem impulsos originais. Não existe uma só ideia deposta entre os tesouros intelectuais da humanidade que seja oriunda do Brasil". O brasileiro era "um povo de quarta ou quinta ordem, quanto às lutas do pensamento" (Romero, 1969:136-137). As coisas não estavam melhores do ponto de vista estético. Num estudo chamado Belas artes (1889), em que descrevia e avaliava o estado delas entre nós, o barão do Rio Branco (IHGB e ABL) declarava que, "no Brasil, como na maior parte da América do Sul, a cultura das artes não está ainda suficientemente desenvolvida". De notável, a época colonial legara apenas o Aqueduto da Carioca e "algumas igrejas de estilo jesuítico com imitações desastrosas do antigo, e alguns vastos edifícios, mais sólidos do que graciosos, que serviram de residência aos governadores e aos vice-reis". No que diz respeito à escultura, o país produzira um único "estatuário de real mérito"; quanto à arquitetura, ela lhe parecia mesmo ter regredido. Sua conclusão geral era desalentadora: "Seria preciso recomeçar a obra mal tentada por D. João VI, chamando ao Brasil, durante uma vintena de anos, professores estrangeiros" (Rio Branco, 2000:130-140). Em 1896, Clóvis Beviláqua (outro futuro membro da $\mathrm{ABL}$ ) reconhecia que o "Brasil não contribuiu com uma escola própria, sequer com um conceito original de vulto, para a desenvolução da filosofia humana". A atividade filosófica entre nós só poderia ser compreendida como composta da repercussão do movimento europeu no Brasil (Beviláqua, 1975: 66). O brasileiro lhe parecia ter voo baixo para a especulação intelectual: "Faltam-nos asas para esses voos" (Idem:100). As mesmas considerações pessimistas se encontram nos inventários da literatura brasileira. Em sua História da literatura brasileira (1912), José Veríssimo (IHGB e CPII) avaliava a produção literária nacional da seguinte forma:

Uma literatura (...) só existe pelas obras que vivem, pelo livro lido, de valor efetivo e permanente e não momentâneo e contingente. A literatura brasileira (...) é uma literatura de livros na máxima parte mortos, e sobretudo de nomes, nomes em penca, insignificantes, sem alguma relação positiva com as obras. (...) Não pode haver maior argumento da sua desvalia (Veríssimo, 1963:14).

A aceitação da filosofia eurocêntrica da história, que tornava a produção intelectual dotada de originalidade privativa das potências euro- 
peias, se refletiu, assim, na sua preferência pelo produto cultural oriundo daqueles países, em detrimento dos próprios, vistos invariavelmente como inferiores, precários, parciais, locais. Ao se dirigir aos diplomatas estrangeiros chegados ao Rio para a Exposição de 1922, o próprio presidente da República, Epitácio Pessoa (ex-professor da Faculdade de Direito do Recife), foi o primeiro a preveni-los de que de que a cultura brasileira "naturalmente" não estava ao nível daqueles dos países "mais adiantados em civilização". Depois de desculpar-se com o "argumento etário" da juventude da nação, que só contava um século de existência, Epitácio pediu aos presentes a sua indulgência: o Brasil estava no bom caminho, ele afirmava, pois estava emulando os bons exemplos dos países cêntricos, a que eles pertenciam - países que eram, afinal, os protagonistas verdadeiros da história universal:

Vejais que não ficamos estacionários; que o Brasil, compenetrado da missão que lhe cabe na cena internacional, tem prestado devotadamente o seu concurso à obra da civilização em que viveis empenhados e é digno da consideração com que o honrais neste momento - vós, que decerto reconhecereis no esforço pertinaz da nossa adolescente nacionalidade a promessa de uma larga política de realizações (Pessoa, 1961:155; ênfases minhas).

\section{O PENSAMENTO POLÍTICO BRASILEIRO SOB O SIGNO DO NACIONALISMO PERIFÉRICO (1922-1970)}

O advento de um paradigma cultural nacionalista entre as duas guerras mundiais desencadeou no subcontinente uma mudança importante no modo de conceber o lugar dos países periféricos no mundo e de aferir a qualidade da sua produção cultural. A crítica às concepções evolucionistas unilineares que haviam predominado sob o paradigma cosmopolita permitia identificar a singularidade da cultura de cada nacionalidade. Essa crítica matizava a crença na universalidade dos modelos, avançando, em seu lugar, a tese de que cada país possuía uma trajetória própria; que não havia linearidade, mas pluralidade das linhas de evolução nacional. Por outro lado, a singularidade da trajetória de cada país se refletia na especificidade de sua cultura, que ganhava também, ao menos potencialmente, o selo de "originalidade".

Entre nós, Oliveira Viana (IHGB e ABL) já proclamava, na introdução de Evolução do povo brasileiro (1956 [1a edição, 1922]), a inexistência de "leis gerais da evolução dos povos", conforme haviam pregado Com- 
te, Marx, Spencer, Darwin e Haeckel. Ele pregava a necessidade de que os intelectuais brasileiros voltassem suas atenções para o nosso passado. Pelo conhecimento das singularidades de sua formação, seria possível compreender as leis da nossa evolução e colaborar para a superação de nossa condição periférica: "Nenhum erro maior do que o daqueles que, partindo de uma suposta identidade entre nós e os outros grandes povos civilizados (porque temos a mesma civilização), julgam-se dispensados de estudar o nosso grupo nacional nas suas peculiaridades", afirmava Viana. Daí a "necessidade de estudarmos o nosso povo em todos os seus aspectos; no imenso valor prático destes estudos: somente eles nos poderão fornecer os dados concretos de um programa nacional de reformas políticas e sociais" (Viana, 1956:39). O apelo de Viana não caiu no vazio. Nas duas décadas seguintes vieram a lume os principais clássicos da formação nacional, como Casa-grande e senzala, de Gilberto Freire; Raízes do Brasil, de Sérgio Buarque de Holanda; a Aventura política do Brasil, de Azevedo Amaral, ou Formação do Brasil contemporâneo, de Caio Prado Jr. Surgiram então também obras de análise política que teriam impacto por muitas décadas, como Eleição e representação, de Gilberto Amado; Brasil errado, de Martins de Almeida, O sentido do tenentismo, de Virgínio Santa Rosa; Maquiavel e o Brasil, de Otávio de Faria. Esse novo contexto nacionalista também se refletiu no surgimento das primeiras histórias do pensamento político brasileiro, destituídas de viés autodepreciativo, como Inteligência do Brasil, de José Maria Belo, e Orientações do pensamento brasileiro, de Nélson Werneck Sodré (Oliveira, 1995:111-112).

A contribuição intelectual decisiva no sentido de rejeitar o papel de passivo espectador do movimento do mundo se deu pela recepção do historicismo pós-helegiano da escola de Dilthey, promovida por Ortega y Gasset no mundo ibero-americano. Ortega y Gasset estava preocupado com o lugar da atrasada cultura espanhola numa época em que o imperativo da superação do atraso prescrevia aos países periféricos conscientes do seu atraso romper com a sua atrasada identidade cultural. Resolver o dilema era impossível no quadro da cronosofia cosmopolita hegeliana, que pusera a filosofia "em um ponto de vista universal humano, rebelde às determinações concretas do espaço e do tempo, isto é, da história" (Zea, 1956:103). O contato com o historicismo pós-hegeliano ajudara Ortega y Gasset a resolver o impasse entre nacionalismo reacionário e cosmopolitismo modernizador, adotando uma via intermédia pela qual o passado cultural nacional era assumido e convertido em experiência vital, sem a obrigação de preservá-lo a 
qualquer custo. A lição de Ortega y Gasset foi assimilada pelos estudiosos ibero-americanos: a revelação dos vínculos intrínsecos do pensamento com as circunstâncias históricas revelava-lhes a similitude essencial entre os processos intelectuais europeus e americanos e a dimensão simultaneamente nacional e universal de qualquer conhecimento, que tornava sem sentido hierarquizá-los. O perspectivismo orteguiano resolvia a oposição entre vida e cultura, entre tradição e ciência, ao historicizar e relativizar o conhecimento. Ele permitiria aos intelectuais ibero-americanos pensar os seus produtos intelectuais, conferindo-lhes "a dignidade de uma filosofia, a dignidade de uma ciência" (Idem:105).

Entretanto, não se deve imaginar que a mudança de paradigma - do cosmopolita para o nacionalista - tenha sido de tal monta, que essas obras se traduzissem invariavelmente no reconhecimento de uma igualdade da sua reflexão frente àquela dos países cêntricos. Considerar e hierarquizar as diversas nacionalidades no plano de uma "história universal" não significava equiparação automática entre eles no plano da dignidade. Embora matizada e relativizada, o elemento evolutivo da filosofia da história oitocentista - e, com eles, a sua produção intelectual - permanecia, porém, a escaloná-los. Euclides da Cunha já exprimia essa perspectiva do nacionalismo periférico em 1907: “Mais vale ser um original do que uma cópia, embora esta valha mais do que aquele. O ser brasileiro de primeira mão, simplesmente brasileiro, malgrado a modéstia do título, vale cinquenta vezes mais do que ser a cópia de segunda classe, ou servil oleografia, de um francês ou de um inglês" (Cunha, 1975:114). A antiga classificação entre países civilizados e bárbaros foi substituída por outras que, embora supusessem a vocação de todos para se encontrarem na "linha de chegada", não deixava de reconhecer que eles se achavam em graus diferentes de "desenvolvimento" (novo nome do velho "progresso" ou "civilização"). Da mesma forma, o reconhecimento de um lugar a cada nacionalidade e à sua respectiva cultura não significava que uma e outra estivessem à altura de seus equivalentes cêntricos. Era possível assim reivindicar a singularidade e a originalidade da cultura nacional, sem prejuízo de seu caráter exótico, ou subalterno, quando comparadas aos países cêntricos.

Forjou-se, por força do caráter crítico do paradigma nacionalista, adaptado pelos nacionalistas ibero-americanos, a perspectiva daquilo a que chamarei inserção subalterna da cultura ibero-americana. Diferentemente do paradigma anterior, quando o produto intelectual periféri- 
co estava simplesmente à margem da civilização, porque desprovido de originalidade, reconhecia-se que ele estava integrado ao movimento intelectual do mundo e que ele tinha o seu valor. No entanto, ele era considerado qualitativamente inferior aos dos países cêntricos, ficando seu valor adstrito à nação que o havia produzido, para fins de autoconhecimento e valorização de sua cultura. Passava-se da condição de uma não cultura para a de uma meia cultura, quando comparada àquela dos países cêntricos. Exemplo de internalização da nova concepção da inserção subalterna da cultura periférica na "história universal" pode ser encontrado na obra clássica de José Luis Romero sobre o pensamento político argentino (2008 [1a edição, 1944]). Para Romero, haveria dois tipos de reflexão política: "vigoroso e original", o primeiro deles era produzido em países como a Inglaterra, a França, a Alemanha; o segundo, constituído de "arremedos de ideias", em decorrência de sua condição de países colonizados, seria elaborado em países como Argentina, Brasil e Chile. É verdade que aqueles "arremedos" eram importantes para os países ibero-americanos, pois serviam para que eles se conhecessem e pudessem modificar seus destinos. Bem se vê, todavia, que o interesse em conhecer o pensamento periférico não se justificava no seu valor heurístico intrínseco (como o europeu), mas como mero documento histórico do passado nacional:

Nem na Argentina nem no resto dos países hispano-americanos floresceu um pensamento teórico original e vigoroso em matéria política, nem era verossímil que florescesse. Mas (...), à parte o que seja ou não original no plano doutrinário, o pensamento político de uma coletividade possui sempre um altíssimo interesse histórico; não somente enquanto é ideia pura, mas também - e acaso mais - enquanto é consciência de uma atitude e motor de uma conduta (Romero, 2008:10).

No Brasil, entre 1930 e 1970, três instituições se notabilizaram por pensar o problema da cultura brasileira no mundo e no seu respectivo status: o Instituto Brasileiro de Filosofia (IBF), o Instituto Superior de Estudos Brasileiros (Iseb) e a Faculdade de Filosofia, Letras e Ciências Humanas da Universidade de São Paulo (FFLCH-SP).

Os responsáveis pela parte mais expressiva dos estudos de história do pensamento político no período foram os juristas e filósofos do Instituto Brasileiro de Filosofia (IBF), fundado em 1949 por Miguel Reale, catedrático de filosofia do direito do Largo de São Francisco. A criação do instituto se deu no contexto de reação dos filósofos ibero-americanos à tese de que a produção daquele saber fosse um monopólio europeu. A 
ambição filosófica de Miguel Reale era a de dar ao Brasil um lugar no mundo filosófico universal, para além da mera exegese do pensamento estrangeiro. Ao instituto se filiaram outros intelectuais da cena brasileira, como Djacir Menezes, Antônio Paim, Paulo Mercadante, Vicente Barreto e Ubiratan Borges de Macedo, no Rio de Janeiro; Luís Washington Vita e Roque Spencer Maciel de Barros, em São Paulo; e Nélson Saldanha, em Pernambuco (Paim, 1981: 93). Orientado por um autonomismo de tintas conservadoras, o IBF se opôs à perspectiva de inserção subalterna do pensamento brasileiro, considerando-a questão de princípio. "O objetivo da história das ideias, que tanto pode se referir à cultura universal como à civilização de cada país" passava, para Reale, por "indagar das raízes e desenvolvimento das produções humanas que lograram se converter em signos ou momentos da vida espírito". O maior erro que se poderia cometer na formulação de nossos juízos críticos era o de espelhar-se "tão somente em arquétipos da cultura universal". Era preciso considerar "as conjunturas históricas que condicionaram a recepção das teorias concebidas nos grandes centros científicos ou artísticos, e, por conseguinte, o papel que aqueles modelos ideais podiam desempenhar em nosso acanhado mundo intelectual" (Reale, 1994:11-12). Também para Antônio Paim, participando do caráter universal da filosofia, as filosofias nacionais se distinguiriam umas das outras apenas por privilegiarem determinados problemas filosóficos em detrimento de outros (Paim, 1984:13).

Entretanto, esse intuito de romper com a inserção subalterna esbarrava na dificuldade sentida pelos membros do Instituto de se livrarem da concepção essencialista hegeliana de ideia, vista como um ente universal, absoluta e desencarnada, que se manifestava na história da cultura como dotada de originalidade. O resultado era previsível: todos eles acabavam concluindo que, devido ao recente passado colonial brasileiro, não era adequado falar em filosofia brasileira. Não houvera tempo, alegava-se, para que se formasse entre nós uma corrente autônoma, orgânica, original de ideias. Para os ibefianos, a filosofia brasileira parecia na verdade avessa à especulação, sendo essencialmente pragmática. Em 1956, Cruz Costa escrevia: "A nossa origem, as condições de nossa formação, a nossa experiência histórica, nos afastam do alcantilado das metafísicas e nos impelem para a meditação das realidades concretas e vivas" (Costa, 1956:1). Luís Washington Vita engrossava o coro: haja vista que o esforço da reflexão latino-americana passava por conhecer a realidade social, econômica, cultural e geográfica do continente para transformá-lo e modernizá-lo, a filosofia e a sociologia aca- 
bavam sendo produzidas por razões de ordem pragmática. O "realismo social" que atravessara a reflexão brasileira decorreria desse "desencanto, da consciência de que o fracasso se deve ao divórcio entre os sonhos do ingênuo racionalismo dos fundadores e uma realidade social inadequada para a realização desses ideais, uma realidade social que eles desconheciam por completo" (Vita, 1965:4). Não se estava distante do diagnóstico de Clóvis Beviláqua, segundo o qual o futuro da filosofia brasileira não viria dos "cimos elevados da metafísica" (Beviláqua, 1975:66).

O futuro dos estudos "filosóficos" estava naquilo que por eles já se estava chamando de "pensamento brasileiro". Em 1956, Djacir Menezes publicava no Rio de Janeiro uma coletânea de artigos de diversos autores intitulada $O$ Brasil no pensamento brasileiro, que reunia páginas de autores interpelados pelos problemas do desenvolvimento (isto é, da superação do "atraso") e representativos do "alvorecer da consciência nacional" - não apenas sociólogos e políticos, mas também literatos e poetas. O tom da coletânea era pedagógico-patriótico: aos olhos do seu autor, o mérito dela estava menos em "ler cuidadosamente os autores nacionais para compreender os problemas sociais e políticos", do que em "selecionar ensinamentos sobre aqueles problemas". O objetivo era o de levar o leitor a "amar a Pátria na Verdade e na Justiça, com a verificação de seus valores autênticos, que os há reconhecidos e reconhecíveis" (Menezes, 1972:19 e 21). O pensamento brasileiro não podia ser qualificado como um decalque das concepções estrangeiras, nem mesmo "quando os autores parecem repetir o que está na literatura europeia". E explicava por quê:

As ideias, que se importam e ensaiam aplicar ao Brasil, encontram maior ou menor ressonância segundo as circunstâncias sociais e políticas nativas: e sua estranheza em relação ao meio teria, como consequência, a desadaptação intelectual das elites, falseando-lhes a compreensão do desenvolvimento histórico e de suas leis internas. Tal fato despertaria correções - porque as ideias são em toda parte instrumentos de ação, mesmo que não pareçam; e nesta hipótese, inscrevem-se na convivência humana, onde se transformam em forças à medida que representam aspirações, projeções de interesses, vitalidade (Idem:10).

Para fugirem do fantasma da condição periférica, que os assombrava com a falta de originalidade, os filósofos do IBF decidiram, então, abraçar aquela parte do acervo intelectual nacional que mais lhes parecia conter algo de único: a "filosofia social", que reunia alguma coisa de 
ética, outro bocado de estética, e muita política. Nelas, percebia-se que, ao receber as ideias europeias, o Brasil as adaptara, de modo a conferir-lhe um colorido particular. O objeto de uma história intelectual brasileira deveria recair, portanto, sobre o modo como a filosofia europeia foi recepcionada no Brasil - entendendo-se aqui, por recepção, a apropriação ativa de autores, ideias e temas de um sistema cultural-intelectual para os propósitos de outro: "Na maneira de sermos influenciados poderá residir algo de próprio e singular" (Reale, 1998:75).

Por outro lado, partindo da premissa de que, para além da nossa "filosofia social", a produção intelectual nativa não alcançava qualidade, era preciso reconhecer que seria exagerado pretender inventariá-las numa "história da filosofia do Brasil". Na melhor das hipóteses, seria possível elaborar, no lugar daquela, uma "história das ideias filosóficas no Brasil". A mudança de terminologia queria dizer que, para os membros do IBF, a filosofia não era nacional, mas universal; e que, no Brasil, não havia um encadeamento de pensadores originais, profundos e coerentes. E as histórias das ideias não tardaram. Em seus ensaios de 1962, Miguel Reale empregava como equivalentes as expressões "história das ideias no Brasil" e "história do pensamento brasileiro". Obras gerais sobre o pensamento político brasileiro, publicadas por Nélson Saldanha e João Camilo de Oliveira Torres, chamaram-se, respectivamente, História das ideias políticas no Brasil (1967) e Interpretação da realidade brasileira - Introdução à história das ideias políticas no Brasil (1968). Foi também em 1967 que a obra resultante do maior esforço desenvolvido pelo instituto na produção de uma história da filosofia brasileira acabou batizada por seu autor, Antônio Paim, como História das ideias filosóficas no Brasil. Já se consolidava na academia a noção de que, embora valesse a pena ser inventariada, a produção intelectual nacional não era boa o bastante para ser qualificada como "filosofia" (ou "teoria"); que ela só podia ser apreendida em suas manifestações como "pensamento" e estudada por meio de uma "história das ideias". Inserção subalterna, portanto.

Já os intelectuais nacionalistas do Instituto Superior de Estudos Brasileiros (Iseb) se situavam entre o nacionalismo conservador do IBF e o cosmopolitismo cientificista e marxista da USP. A primeira reação do nacionalismo crítico isebiano, diante do acervo intelectual brasileiro, elaborado sob o paradigma cosmopolita, foi o de rejeitá-lo como expressivo da mentalidade alienada e, como tal, inautêntica, típica da condição periférica. O fundador da linhagem que desaguaria no Iseb, 
Alberto Torres, dava o tom das futuras críticas em 1914: nossos intelectuais políticos "bordavam sobre a realidade da nossa vida uma teia de discussões abstratas, ou retóricas; digladiavam-se em torno de fórmulas constitucionais, francesas ou inglesas; tratavam das eleições, discutiam teses jurídicas (...), imitando ou transplantando instituições e princípios europeus" (Torres, 1982a:62). Por isso, não lhe doía afirmar: "Nunca chegamos a possuir cultura própria, nem mesmo uma cultura geral" (Torres, 1982b:14). Em 1922, seu principal discípulo, Oliveira Viana, daria nome a essa ideologia que contaminaria a produção intelectual nacional desde a nossa independência: "idealismo utópico". E explicava do que se tratava:

Entre nós, não é o povo, na estrutura, na sua economia íntima, nas condições particulares da sua psique, que os organizadores brasileiros, os elaboradores dos nossos códigos políticos, vão buscar os materiais para as suas formosas e soberbas construções: é fora de nós, é nas jurisprudências estranhas, e em estranhos princípios, é nos modelos estranhos, é nos exemplos estranhos, é em estranhos sistemas que eles se abeberam e inspiram (Viana, 1939:7).

Voltando ao assunto em 1949, ele recorreria ao dilema do mazombo de modo crítico: "Vivem todos eles [nossos autores políticos] entre duas 'culturas': uma - a do seu povo, que lhes forma o subconsciente coletivo; outra - a europeia ou norte-americana, que lhes dá as ideias, as diretrizes do pensamento, os paradigmas constitucionais, os critérios do julgamento político" (Viana, 1974:19).

Encontramos a mesma postura de rejeição do passado intelectual brasileiro pelo seu caráter antinacional na década de 1950, junto aos intelectuais nacional-desenvolvimentistas reunidos no Iseb. Para Hélio Jaguaribe, Roland Corbisier e Álvaro Vieira Pinto, filosofia ou cultura autenticamente brasileira não poderia ter existido até então, dada a condição de colonial, depois semicolonial do país, marcada pela inconsciência de si. O Brasil havia sido um país formalmente colonizado e depois passara a uma situação semicolonial face aos países cêntricos. Uma vez que a colonização era "um fenômeno social total", o complexo colonial era "globalmente alienado". Resgatando a imagem do Brasil como uma terra sem história nem povo, Corbisier afirmava: "A colônia não é cultura, mas natureza; não é história, mas geografia; não é tempo, mas espaço; não é vigília, mas torpor; não é forma, porém matéria; não é consciência, mas autonomismo" (Corbisier, 1958:69). Em seu inventário sobre a história da filosofia brasileira, Jaguaribe já expressa- 
ra o seu juízo: "Nossa filosofia, até os dias correntes, não tem originalidade e é pouco autêntica" (Jaguaribe, 1957:14). Melhor juízo não era aquele de Nélson Werneck Sodré, cujo nacionalismo marxista condenava o pensamento nacional brasileiro por refletir a ideologia do colonialismo, que legitimava o domínio da classe dominante, pela "adoção servil de modelos externos" extraídos das potências imperialistas (Sodré, 1965:12). Somente àquela altura da década de 1950, graças ao processo acelerado de industrialização, urbanização e integração do mercado interno, a condição semicolonial do país estava em vias de superação; somente então, por conseguinte, surgiam condições objetivas para a produção de uma autêntica cultura brasileira. Era o que explicava Vieira Pinto: a "consciência brasileira, em virtude do ponto a que chegou o processo de desenvolvimento material da nação", a penas então (1956) alcançava "aquele grau de claridade que começa a permitir-nos a percepção exata do nosso ser" (Pinto, 1960:28). Antes, não.

Chefe do departamento de sociologia do Iseb, Guerreiro Ramos foi quem combateu essa postura de rejeição integral do pensamento brasileiro pretérito por parte dos colegas. Guerreiro não discordava do caráter colonizado ou inautêntico do pensamento brasileiro, nem que ele estava em vias de emancipação em meados da década de 1950. De acordo com a filosofia da história corrente na instituição, ele entendia à moda hegeliana que, por não terem história própria, todos os países colonizados ou descobertos eram "versões da história de povos colonizadores, ou material etnográfico destes povos"; daí a inclinação de suas elites por "adotar as ideias alienígenas", obedecendo "à lei da imitação do superior pelo inferior". Tratava-se de um tipo de imperialismo cultural "assegurado pelo próprio fascínio que exercem sobre os colonizados as instituições dos povos conquistadores" (Ramos, 1953:11). Explicava-se desse modo o caráter alienado do pensamento periférico - o seu "idealismo utópico", para recuperar a expressão de Oliveira Viana. Entretanto, o processo de superação da condição colonial ou semicolonial, explicava Guerreiro, era concomitante àquele de superação da mentalidade alienada por parte dos intelectuais. O estudo do nosso passado - e aqui estava sua diferença em relação aos seus colegas - revelava que nem tudo o que aqui se produzira fora cópia servil dos modelos estrangeiros; que havia, ao longo de nossa história, uma tradição de autores que haviam deixado valiosas contribuições no campo do pensamento, vinculadas "à problemática da sociedade brasileira": o visconde de Uruguai, Joaquim Nabuco, Sílvio Romero, Euclides da Cunha, Alberto Torres, Oliveira Viana e Azevedo Amaral, 
por exemplo. Todos eles partiam do pressuposto de que era necessário superar o estado de dependência do país e de alienação de suas elites face aos "países cêntricos". Uma vez que "jamais se chega a constituir uma ciência nacional, se as gerações de especialistas não se articulam no sentido de um labor contínuo" (Ramos, 1957:124), lhe parecia ser sobre aquela tradição que se deveria fundar a nascente ciência social brasileira: "O caminho da autoafirmação do pensamento brasileiro já está aberto, carecendo apenas dos que continuem o trabalho dos desbravadores" (Ramos, 1953:34).

Guerreiro Ramos se destacava, assim, como crítico frontal do caráter etnocêntrico da filosofia da história positivista e marxista, bem como das "teorias da modernização" subjacentes a ela, elaboradas nos Estados Unidos. Em seu livro O processo da sociologia no Brasil (1953), já denunciava o caráter eurocêntrico do ideal sociológico do conhecimento "universal", atribuindo sua aceitação na periferia a uma "superfetação compensatória" decorrente do complexo de inferioridade de suas elites (Ramos, 1953:9). Em toda a parte, as ciências sociais teriam surgido como "instrumentos de decifração nacional" em função de imperativos políticos práticos. No entanto, devido à importância que a filosofia da história possuía no pensamento na década de 1950, o estatuto do pensamento brasileiro ainda não estava de todo isento de ambiguidades em Guerreiro Ramos. Se, por um lado, ele afirmava que os autores referidos constituíam "o elo da ciência brasileira, da teoria social brasileira, que vem se formando por acumulação" (Ramos, 1961:169), por outro, ele ponderava que as obras por eles deixadas refletiam "o grau de consciência possível" da época em que foram elaboradas; que, antes de 1930, ainda não era possível "atingir-se uma concepção configurada da sociedade brasileira" por faltarem então "condições objetivas"; e que de nenhuma delas resultara "a formação de uma ideologia orgânica da realidade brasileira apta a tornar-se o suporte de uma ação política de verdadeiro sentido nacional" (Ramos, 1957:69). Apenas naquele momento (a década de 1950) havia plenas condições de se teorizar a realidade brasileira de modo competente. Esse rescaldo de cronosofia não deixava de rebaixar, em alguma medida, as tentativas anteriores efetuadas no sentido de apreender a realidade política brasileira.

No extremo oposto do IBF, e polemizando contra o Iseb, a instituição onde eram menos favoráveis as condições para a superação ou crítica da perspectiva subalterna era a Faculdade de Filosofia, Letras e Ciências Humanas da Universidade de São Paulo (FFLCH-USP). Devido à 
longamente cultuada formação afrancesada da instituição e por sua ojeriza ao nacionalismo isebiano, percebido como sinônimo de autoritarismo, os uspianos se orientavam por um cosmopolitismo que, fundando-se em critérios qualitativos dotados de alcance "universal", não tinha pruridos em reconhecer a inferioridade da produção brasileira. Eis como o sociólogo Fernando Azevedo avaliava a cultura brasileira em seu livro homônimo, em 1939:

A cultura [brasileira] apresenta graves lacunas e, tanto pela qualidade como pelo volume, sobretudo do ponto de vista filosófico e científico, não se desenvolveu no mesmo ritmo da civilização, apresentando-se ora retardada em relação a outros países de civilização comum, ora marcada pela superficialidade e pelo diletantismo, artificial e "desinteressada pela civilização em que floresceu" (Azevedo, 1963:44).

Dezesseis anos depois, o filósofo João Cruz Costa expunha visão semelhante na sua Contribuição à história das ideias no Brasil: prolongamento da Europa, a América não teria civilização própria, nem filosofia original - tinha apenas esboço de filosofia. Sua posição era a mesma de José Luis Romero na Argentina, quando afirmava que o estudo das "ideias" brasileiras só se justificava na medida em que era preciso conhecer a "experiência americana" da filosofia. O pensamento europeu teria adquirido na América um "estilo" próprio, decorrente do transplante das ideias para este lado do oceano. As "transformações ou deformações" sofridas neste processo era o que tornavam o pensamento brasileiro digno de ser estudado (Costa, 1956). Dois anos depois, em Formação da literatura brasileira, o crítico literário Antônio Cândido reiterava a perspectiva da inserção subalterna, partilhada por seus colegas da sociologia e da filosofia. Embora reconhecesse a peculiaridade da literatura brasileira, o autor não deixava de reconhecer a sua inferioridade, quando comparada à dos países cêntricos: "Comparada às grandes, a nossa literatura é pobre e fraca". Ela era "um galho secundário da portuguesa, por sua vez arbusto de segunda ordem do jardim das musas" (Cândido, 2008:11). Ou seja, era uma literatura de terceira categoria.

Nos anos 1950, o estudo do pensamento brasileiro acabou interditado na sociologia uspiana por considerações derivadas da filosofia da história. Desta vez, sua inferioridade não foi decretada a partir dos critérios "universais" (cêntricos) do que fosse a filosofia, mas sim do que fosse a "ciência". Florestan Fernandes alegava em Desenvolvimento histórico-social da sociologia no Brasil (1956) que o trabalho do cientista social deveria ser examinado "à luz das obrigações, dos procedimentos e 
dos ideais que possuem caráter 'universal'" (Fernandes, 1977:50). A cronosofia por ele mobilizada não era a hegeliana, cultural-nacional, de livre curso no IBF e no Iseb, mas a positivista, elaborada por Comte e amaciada por Durkheim. Examinando a partir dessa matriz o "progresso da ciência social" brasileira, Florestan postulava que, apenas em 1920, tivera início no Brasil "a transição da análise histórico-sociológica, descritiva ou pragmática em investigação positiva" (Idem: 42). O principal marco desse progresso era a fundação da própria Universidade de São Paulo, onde lecionava, e, nela, do departamento de sociologia, de que ele era o chefe. Praticado por bacharéis em direito e jornalistas, o pensamento brasileiro pretérito era descartado como "ensaísmo", ideológico ou parassociológico, típico de uma etapa ultrapassada da vida científica brasileira, que participava agora do movimento "universal" da sociologia. Os estudos da sociologia não deveriam partir, assim, das anteriores hipóteses veiculadas pelos pensadores brasileiros, porque o seu valor era apenas histórico. Nesta perspectiva, tudo o que os sociólogos poderiam fazer a respeito dos autores brasileiros do passado era estudá-los como tais, enquanto grupo, deixando de lado a questão do valor heurístico das obras por eles deixadas, e que deveriam ser consideradas somente no plano de suas estratégias de ascensão social. Em outras palavras, se um dia o fizessem, os sociólogos uspianos poderiam estudar os autores brasileiros do passado somente no plano de uma sociologia dos intelectuais, deixando de fora a possibilidade de estudar suas obras como representativas de uma sociologia brasileira. Produzida a partir da década de 1970, a obra de Sérgio Miceli não romperia, pelo menos neste aspecto, com a lógica de Florestan Fernandes.

A filosofia da história positivista não era a única a ter livre curso na FFLCH-USP. Porque, na sua vertente mais dogmática, tendia a refutar como ideológico quase tudo o que se produzira no país, a filosofia marxista da história renovou os antigos obstáculos para a superação da perspectiva da "inserção subalterna" do pensamento brasileiro. $\mathrm{O}$ marxismo dera pela primeira vez o ar de sua graça no campo em 1954, quando Dante Moreira Leite defendera na faculdade de pedagogia sua tese intitulada $O$ caráter nacional brasileiro: história de uma ideologia (1954). Esta última era definida como um "obstáculo no processo pelo qual uma nação surge entre as outras, ou pelo qual um povo livre surge na história", e acusava os autores do pensamento brasileiro de encobrirem a realidade de luta de classes no país (Leite, 1992:329). O advento do regime militar, dez anos depois, acirrou a aversão dos uspianos ao 
nacionalismo e entronizou o marxismo como sua linguagem acadêmica. Naquele contexto, uma história das ideias políticas no Brasil só valeria na medida em que fizesse a denúncia do traço autoritário que, desde o período colonial, atravessaria a nossa cultura política. A "história das ideias" só podia existir como "história das ideologias". Nesse quadro, não admira que um dos primeiros textos modernos acerca do pensamento político da independência, elaborado na Faculdade de História por Maria Odila Leite da Silva Dias, tivesse por título Ideologia liberal e construção do Estado (1976). Ao publicar em 1977 seu livro Ideologia da cultura brasileira, o também historiador Carlos Guilherme Mota declarava pretender denunciar por meio dele tudo o que, entre nós, se produzira "no sentido de mascarar, justificar, desviar ou diagnosticar os processos vividos" (Mota, 1977:21, 50). Naquele mesmo ano, Caio Navarro de Toledo condenava em sua tese o pensamento nacionalista dos isebianos, acusando aquela instituição de ter sido uma "fábrica de ideologias". Por ideologia, entendia-se aqui "a ideologia da classe dominante: mistificadora, dissimuladora", em contraposição à ciência que, por sua vez, equiparada ao marxismo, seria aliada ou instrumento natural das classes dominadas (Toledo, 1977:21-22).

A partir da segunda metade da década de 1960, a chamada teoria da dependência de Fernando Henrique Cardoso facultou a diversos professores da instituição uma abordagem que, embora marxista, era menos dogmática e, portanto, menos improdutiva para a análise do pensamento político brasileiro. Ao invés de descartarem como ideologia burguesa o pensamento político brasileiro, muitos professores passaram a se interessar pelo modo por que o Brasil recepcionara o ideário oriundo dos países centrais, especialmente na história e na literatura. No entanto, diferentemente dos ibefianos, os uspianos salientavam o modo equivocado ou desviante por que aquelas ideias politicas teriam sido recepcionadas ${ }^{11}$. Deslocadas da estrutura social e econômica original dos países cêntricos, ao serem absorvidas pela elite brasileira, rural, escravista, analfabeta, as ideias políticas no Brasil acabaram condenadas à esterilidade, à deformação ou à hipossuficiência (Carvalho, 1998:124-125). Em 1967, Cruz Costa afirmava que "as culturas estranhas", isto é, cêntricas, expressavam "uma experiência histórica mais rica do que a nossa". A vida intelectual brasileira restara prejudicada pelas "contradições existentes em nossa história, relacionadas com as vicissitudes da adaptação das ideias de importação e as estruturas socioeconômicas sobre as quais ainda pesa o resíduo de um passado colonial" (Mota, 1968:9). No ano seguinte, a historiadora Emília Viotti da 
Costa assegurava que o liberalismo oitocentista brasileiro não teria sido eficaz em seus efeitos supostamente liberatórios porque era estranho ao meio para o qual fora transportado (Costa, 1968:90). A imagem da periferia a desfigurar as ideias cêntricas reaparecia no célebre ensaio de Roberto Schwarz, As ideias fora do lugar (1972), em que o autor afirmava que a importação da ideologia liberal burguesa europeia para uma sociedade escravista e latifundiária, como a brasileira, resultara numa verdadeira "comédia ideológica" (Schwarz, 2000:25). Em outras palavras: o pensamento político, ou permanecia estranho ao meio e passava a ser empregado pela elite culta para fins de ornamentação, ou, se aplicado, terminava "deformado" em relação à sua matriz europeia.

\section{CONCLUSÃO}

Não há como desvincular o estudo da história do pensamento brasileiro da visão de mundo daqueles que o produziram, de acordo com a qual o Brasil se achava na periferia do mundo "civilizado". Assim é que, nela, o emprego da palavra "pensamento" no lugar de "teoria", para designar os seus produtos intelectuais, parece já embutir o reconhecimento da sua inferioridade. Havia implícita uma espécie de divisão do trabalho intelectual: os países cêntricos produziriam a "teoria", ou a "ciência", ou a "filosofia", ou seja, reflexões de alcance "universal" e, portanto, mais densas, mais abstratas, mais generalizantes, ao passo que os países periféricos produziriam somente "pensamento", reflexões de alcance puramente particular ou local, de caráter menos abrangente e contingente, orientado para a ação prática. Quem produzia teoria era um autor, isto é, um especialista, um acadêmico, um cientista. Quem produzia pensamento, ao contrário, era um ator, voltado para a aplicação da teoria para um contexto mais circunscrito no tempo e no espaço. O pensamento se caracterizaria pela aplicação prática, por parte dos atores dos países periféricos, à sua realidade política específica, concreta e particular, da teoria político-social produzida por autores que, instalados nos países cêntricos, elaborariam uma reflexão dotada de um nível maior de abstração e uma pretensão de validade universal. O pensamento era considerado um subproduto da teoria, tanto quanto se considerava a periferia um subproduto do centro, e os atores políticos, subproduto dos autores. O pensamento periférico, entendido como um ramo de segunda ordem, qualitativamente inferior ao europeu, porque examinado por meio de critérios como "originalidade", só teria serventia para os membros da própria comunidade igualmente 
periférica que o produzira. O centro produziria teoria, filosofia e ciência na forma de tratados originais e universais; da periferia, só se poderiam esperar pensamentos ou histórias das ideias, plasmados em ensaios sem originalidade ou simplesmente de baixa densidade intelectual.

Entretanto, o artigo mostrou que esse quadro não permaneceu estático. Ao longo do século XX, houve uma atenuação do grau de inferioridade do pensamento brasileiro na percepção de suas elites, que acompanhou a mudança de atitude imposta pelo paradigma nacionalista, adaptado para a periferia. Ela foi impulsionada pelas transformações operadas no âmbito da estrutura social, política e econômica brasileira, no sentido de uma maior urbanização, demografia, integração do mercado interno e desenvolvimento social e tecnológico. Por outro lado, aquele "crescendo" experimentou certa interrupção em 1964, quando o advento do regime militar levou parte significativa da intelectualidade a instrumentalizar o estudo do passado nacional para denunciá-lo por seu caráter autoritário. Ao mesmo tempo, apesar de matizada, persistia uma abordagem tributária de uma cronosofia etnocêntrica, que pensava a ideia como um ente essencializado, absoluto, desencarnado das pessoas, que tinha um "lugar" (o "centro") e que sofria forçosamente alterações qualitativas negativas quando transferido a outro (a "periferia"). Esses vaivéns decorrentes do acidentado processo brasileiro de democratização e da expansão do seu capitalismo, entre as décadas de 1940 a 1970, se refletiram - em graus maiores ou menores - no juízo acerca do valor do pensamento político brasileiro expresso por intelectuais das três instituições aqui examinadas, ainda que de modo panorâmico: o IBF, o Iseb e a FFLCH-USP.

Por fim, o quadro descrito não parece mais representativo da situação atual. O processo de superação da "condição periférica", ao menos no que diz respeito à avaliação do pensamento político-social brasileiro, sofreria uma primeira importante inflexão na década de 1970, com a pesquisa de Wanderley Guilherme e o debate sobre o pensamento autoritário brasileiro; e uma segunda, nos últimos quinze anos, ao longo dos quais erodiram muitos dos pressupostos por que se justificara, no passado, a crença da inserção subalterna da nossa cultura no quadro mundial. Para tanto, contribuíram a denúncia das concepções culturais etnocêntricas vigentes na nossa sociedade desde a segunda metade da década de 1980 e a própria crise do eurocentrismo, agravada nos últimos anos pela estagnação econômica daquele continente e sua decadência relativa frente aos novos poderes emergentes oriundos de sua 
antiga periferia - entre os quais o próprio Brasil. Por fim, com a crise do marxismo soviético, esgotou-se a própria filosofia da história. Hoje, raros são os estudiosos brasileiros que ainda têm a coragem de proclamar - em público, ao menos - a inutilidade do estudo do pensamento nacional em razão de sua "inferioridade". Mas essa reorientação parece ter ocorrido antes de modo intuitivo do que em função de uma crítica adequada à matriz anterior.

Muitas questões permanecem abertas. Este texto esteve mais preocupado em comprovar a má impressão que nossos próprios intelectuais tinham do nosso pensamento político do que em esmiuçar as razões por eles apresentadas para justificá-la. Outras questões ainda estão por investigar. Por que nossos intelectuais consideravam que não existia o povo? Em algum momento, mudaram de diagnóstico? De que modo os "males da formação nacional" afetaram a percepção da qualidade ou da própria existência do pensamento político nacional? Como foi que cada modalidade de filosofia da história - a liberal, a positivista, a culturalista e a materialista - impactou no processo de cognição sociopolítica nacional e se refletiu, em cada época, na forma de se avaliar nossos produtos intelectuais? Compreendido de modo detido a maneira por que o pensamento político foi fabricado na periferia, será possível, mais adiante, sugerir um método alternativo de estudá-lo, apto a suprimir a distinção qualitativa entre "teoria política" ("universal" - cêntrico - superior) e "pensamento político" ("local" - periférico - inferior). Essa tarefa passa, também, pela superação da consideração das "ideias políticas" como dotadas de vida e lugar próprios, bem como de sua indeclinável historicidade. Este texto constitui uma primeira tentativa de compreender a história da história do pensamento político brasileiro, a fim de que, conhecidas as premissas sobre a qual ele e seu estudo se assentam, seja possível, mais adiante, sugerir formas alternativas e mais produtivas de investigá-lo.

(Recebido para publicação março de 2013)

(Reapresentado em julho de 2013)

(Aprovado para publicação em outubro de 2013) 


\section{NOTAS}

1. É verdade que a maior parte dessas obras versa sobre o pensamento social do Brasil em geral e não apenas sobre sua parte política. Mas a subárea cresce junto com a área como um todo.

2. Esse caráter fundador da pesquisa é reconhecido mesmo pelos seus críticos, como Bolívar Lamounier (1982:430) e Gildo Marçal Brandão (2007:25).

3. A simples tentativa de responder tais momentosas questões, no âmbito do projeto de pesquisa elaborado por Gildo Marçal, teria um alcance extraordinário: ela poderia criar novos instrumentos para analisar obras e autores no contexto do próprio processo político brasileiro. Da mesma forma, se ela tivesse tido lugar, teria sido possível realizar interpretações de conjunto e de maior fôlego do pensamento brasileiro, que lhe permitiria ir além da mera descrição atomizada dos argumentos dos autores canônicos, ou da comparação de seu pensamento no plano teórico.

4. Pronunciada a 10 de maio de 2013 no Laboratório de Teoria e Historiografia da Pontifícia Universidade Católica do Rio de Janeiro (PUC-RJ).

5. É neste sentido que, no texto introdutório da coleção em vários volumes denominada História da Teoria Política, Fernando Vallespín, seu organizador, responde à questão: "Nos momentos atuais, a opção por um ou outro título parece responder mais à necessidade de cumprir com a denominação convencional das distintas especialidades acadêmicas de cada país que a autênticos critérios metodológicos. O que na França é quase unanimemente classificado como Histoire des idées politiques vem a corresponder à politische Theoriengeschichte alemã ou à History of Political Thought anglo-saxã, que são os termos dominantes nesses países" (Vallespín, 1990:7).

6. Encontramos a distinção implícita na própria coleção de Fernando Vallespín, que intitula o capítulo dedicado a Hegel de "filosofia política"; o de Stuart Mill de "teoria política", e aquele de Donoso, Balmès e Martinez de Rosa de "pensamento político".

7. Assim, por exemplo, um livro organizado por professores da Universidade de Buenos Aires e publicado em 2001, que cuida da obra de Moreno, Echeverría, Alberdi e Sarmiento, se intitula "Origens do pensamento político argentino". A referida História da teoria política, organizada na Espanha em seis volumes por Fernando Vallespín, na década de 1990, traz, em seus diversos volumes, capítulos referentes ao chamado "pensamento político espanhol" e ao "pensamento político ibero-americano". Em 2000, a Editorial Trotta deu à luz também um livro chamado "O pensamento social e político ibero-americano do século XIX".

8. "O hispânico de agora, como de ontem, se lamenta, não tanto pelo que não possui, mas pelo que podendo possuir não tem. Formando parte, como formava, da cultura europeia; sendo, como era, parte da história por excelência, que ele, o hispânico, não pôde fazer e que agora se vê obrigado a realizar. O hispânico não quer começar a história como se nada estivesse feito; simples e puramente quer formar parte da história que se vinha fazendo, da história já feita pelo espírito, como assinalava Hegel, que outra coisa não faz senão tomar consciência de si mesmo; realizar-se a si mesmo, ler-se num livro que foi escrito desde a eternidade. Tudo o que está fora deste espírito não poderá ser outra coisa, que um arremedo da história" (Zea, 1983:158).

9. Na França oitocentista, Hegel era visto como o filósofo do pan-germanismo e, como tal, vitimado pelos nacionalismos conflitantes dos países, cuja tensão foi maximiza- 


\section{Christian Edward Cyril Lynch}

da depois da Guerra Franco-Prussiana. Apenas na virada da década de 1920 para a de 1930 começou a haver uma introdução e recepção da filosofia hegeliana na França de modo mais aberto e sistemático, por parte de estudiosos como Jean Wahl, Alexandre Kojève e Jean Hyppolite. Seja como for, a primeira tradução francesa do corpus hegeliano só foi feita na década de 1860 (Bohm, Mudimbe, 2010:8).

10. Embora houvesse histórias da literatura em sentido amplo (como as de Norberto de Sousa, Sílvio Romero e José Veríssimo), não faltaram ensaios de história da filosofia, escritos por Sílvio Romero e Clóvis Beviláqua. Algumas histórias constitucionais da lavra de Aurelino Leal e Agenor de Roure, efetuadas na década de 1910, eram o que mais se aproximava de uma história do nosso pensamento político.

11. Em 1977, o próprio Fernando Henrique Cardoso aludiria em livro aos "efeitos da dependência sobre a produção das ideias", citando como autores comprometidos com aquela visão justamente Cruz Costa, Antônio Cândido e Roberto Schwarz (Cardoso, 1980:17-18). 


\section{REFERÊNCIAS BIBLIOGRÁFICAS}

ALMEIDA, Martins de. (1932), Brasil Errado: Ensaio Político sobre os Erros do Brasil como País. Rio de Janeiro, Schmidt Editor.

AMADO, Gilberto. (1963), Três Livros: A Chave de Salomão e Outros Escritos; Grão de Areia e Estudos Brasileiros; A Dança sobre o Abismo. Rio de Janeiro, José Olympio.

ANAIS do Parlamento Brasileiro: Câmara dos Senhores Deputados, 1826-1889 (1889). Rio de Janeiro, Tipografia de Viúva Pinto \& Filho.

AZEVEDO, Fernando. (1963), A Cultura Brasileira: Introdução ao Estudo da Cultura no Brasil. 4a edição, revista e ampliada. Brasília, UnB.

BARRETO, Afonso Henriques de Lima. (1922), Transatlantismo. Careta, Rio de Janeiro, 8 de julho.

BEVILÁQUA, Clóvis. (1975), Obra Filosófica. Volume II: Filosofia Social e Jurídica. Introdução de Santiago Dantas. São Paulo, Edusp.

BOHM, Arnd; MUDIMBE, Valentin-Yves. (2010), Hegel's Reception in France. Disponível em http://web.ics.purdue.edu/ smith132/French_Philosophy/Fa94/hegel.pdf. Acessado em 6 de fevereiro de 2013.

BONFIM, Manuel. (1993), A América Latina: Males de Origem. 4a edição. Rio de Janeiro, Topbooks.

BRANDÃO, Gildo Marçal. (2007), Linhagens do Pensamento Político Brasileiro. São Paulo, Hucitec.

CÂNDIDO, Antônio. (2008), Formação da Literatura Brasileira. 10å edição. Rio de Janeiro, ABL.

CARDOSO, Fernando Henrique. (1980), As Ideias e seu Lugar: Ensaios sobre as Teorias do Desenvolvimento. Petrópolis, Vozes.

CARVAlHO, José Murilo de. (1998), “História Intelectual no Brasil: A Retórica como Chave de Leitura". Revista Topoi, no 1, pp.123-152.

CONDORCET, Jean-Antoine-Nicolas de Caritat, marquês de. (1996), Esboço de um Quadro Histórico dos Progressos do Espírito Humano. Tradução de Carlos Alberto Ribeiro de Moura. Campinas, Unicamp.

CORBISIER, Roland. (1958), Formação e Problema da Cultura Brasileira. Rio de Janeiro, Iseb.

COSTA, Emília Viotti da. (1968), "Introdução ao Estudo da Emancipação Política”, in C. G. Mota (org.), Brasil em Perspectiva. 7ạ edição. São Paulo, Difel.

COSTA, João Cruz. (1956), Contribuição à História das Ideias no Brasil (O desenvolvimento da filosofia no Brasil e a evolução histórica nacional). Rio de Janeiro, José Olympio.

COUTY, Louis. (1988), A Escravidão no Brasil. Tradução de Maria Helena Rouanet. Rio de Janeiro, Fundação Casa de Rui Barbosa.

CUNHA, Euclides da. (1975), Contrastes e Confrontos. São Paulo, Cultrix. . (1999), À Margem da História. São Paulo, Martins Fontes. 


\section{Christian Edward Cyril Lynch}

FERNANDES, Florestan. (1977), A Sociologia no Brasil: Contribuição para o Estudo de sua Formação e de seu Desenvolvimento. Petrópolis, Vozes.

HEGEL, Georg Wilhelm Friedrich. (2006), Introdução à História da Filosofia. Lisboa, Almedina.

GAUCHET, Marcel (org.). (2002), Philosophie des Sciences Historiques: Le Moment Romantique. Paris, Seuil.

HOLANDA, Sérgio Buarque de. (1936), Raízes do Brasil. Rio de Janeiro, José Olympio.

JAGUARIBE, Hélio. (1957), A Filosofia no Brasil. Rio de Janeiro, Iseb.

JAHANBEGLOO, Ramin. (1996), Isaiah Berlin: Com toda Liberdade. Tradução de Fany Kon. São Paulo, Perspectiva.

LAIDLER, Christiane Vieira. (2010), A Segunda Conferência da Paz de Haia-1907: O Brasile o Sistema Internacional no Início do Século XX. Rio de Janeiro, Fundação Casa de Rui Barbosa.

LAMOUNIER, Bolívar. (1982), “Formação de um Pensamento Político Autoritário na Primeira República: Uma Interpretação", in B. Fausto (org.), História Geral da Civilização Brasileira - O Brasil Republicano, vol. 9, 3a edição, Rio de Janeiro, Difel.

LEITE, Dante Moreira. (1992), O Caráter Nacional Brasileiro: História de uma Ideologia. 5a edição. São Paulo, Ática.

LIMA, Manuel de Oliveira. (1967), História da Civilização. 16ạ edição, revista. São Paulo, Melhoramentos.

LÖWITH, Karl. (1977), O Sentido da História. Tradução de Maria Georgina Segurado. Lisboa, Edições 70.

MELLO, Evaldo Cabral. (2002), Um Imenso Portugal: História e Historiografia. São Paulo, Editora 34.

MENEZES, Djacir. (1972), O Brasil no Pensamento Brasileiro. 2a edição. Brasília, Conselho Nacional de Cultura.

MOTA, Carlos Guilherme (org.). (1968), O Brasil em Perspectiva. São Paulo, Difel. (1977), Ideologia da Cultura Brasileira. São Paulo, Ática.

NABUCO, Joaquim. (1949a), Discursos parlamentares. São Paulo, Progresso Editorial. (1949b), Minha Formação. Rio de Janeiro, Jackson Editores.

OLIVEIRA, Lúcia Lippi. (1995), "As Ciências Sociais no Rio de Janeiro", in S. Micelli (org.), História das Ciências Sociais no Brasil. Volume II. São Paulo, Fapesp.

PAIM, Antônio. (1981), "Miguel Reale e a Filosofia Brasileira", in M. Reale (org.), Miguel Reale na UnB. Brasília, UnB.

. (1984). História das Ideias Filosóficas no Brasil. 3a edição, revista e aumentada. São Paulo, Convívio.

PESSOA, Epitácio. (1961), Conferência da Paz, Diplomacia e Direito Internacional. Obras completas de Epitácio Pessoa, volume XIV. Rio de Janeiro, Instituto Nacional do Livro. 
PINTO, Álvaro Vieira. (1960), Ideologia e Desenvolvimento Nacional. 4ạ. edição. Rio de Janeiro, Iseb.

RAMOS, Alberto Guerreiro. (1953), O Processo da Sociologia no Brasil (esquema para uma história das ideias). Rio de Janeiro, [s.n.].

(1957) Introdução Crítica à Sociologia Brasileira. Rio de Janeiro, Editorial Andes Limitada.

. (1961), A Crise do Poder no Brasil (problemas da revolução nacional brasileira). Rio de Janeiro, Zahar Editores.

REALE, Miguel. (1994), Figuras da Inteligência Brasileira. 2a. edição. São Paulo, Siciliano.

. (1998), Pluralismo e Liberdade. 2a . edição revista. Rio de Janeiro, Expressão e Cultura.

RIO BRANCO; José Maria da Silva Paranhos Filho, barão do. (2000), “As Belas Artes”, in Émile Levasseur (ed.), O Brasil. 1a edição brasileira. Rio de Janeiro, Bom Texto/Letras \& Expressões.

ROMERO, José Luis. (2008), Las Ideas Politicas en Argentina. 2a Edição. Buenos Aires, Fondo de Cultura Económica (1a edição, 1944).

ROMERO, Sylvio. (1969), Obra Filosófica. Introdução e seleção de Luís Washington Vita. Rio de Janeiro, José Olympio.

SANTOS, Wanderley Guilherme dos. (1970), "Raízes da Imaginação Política Brasileira”. Dados, no 7, pp. 137-161.

(2002), Roteiro Bibliográfico do Pensamento Político-social Brasileiro (1870-1965). Belo Horizonte, Ed. UFMG; Rio de Janeiro, Casa de Oswaldo Cruz.

SCHWARZ, Roberto. (2000), Ao Vencedor as Batatas: Forma Literária e Processo Social nos Inícios do Romance Brasileiro. 5a edição. São Paulo, Editora 34.

SODRÉ, Nélson Werneck. (1965), A Ideologia do Colonialismo. 2a edição. Rio de Janeiro, Civilização Brasileira.

STRAUSS, Leo; CROPSEY, Leo (orgs.). (1996), História de la Filosofía Política. México, Fondo de Cultura.

TOLEDO, Caio Navarro de. (1977), Iseb: Fábrica de Ideologias. São Paulo, Ática.

TORRES, Alberto. (1982a), A Organização Nacional. 4ạ. edição. São Paulo, Companhia Editora Nacional.

. (1982b), O Problema Nacional Brasileiro. 4a edição. São Paulo, Companhia Editora Nacional.

VALLESPÍN, Fernando. (1990), “Introducción General”, in F. Vallespín (ed.), Historia de la Teoría Política, 1. Madrid, Alianza Editorial.

VERISSIMO, José. (1963), História da Literatura Brasileira: De Bento Teixeira a Machado de Assis. 4a edição. Brasília, UnB.

VIANA, Francisco José de Oliveira. (1939), O Idealismo da Constituição. 2a edição, aumentada. São Paulo, Companhia Editora Nacional.

. (1956), Evolução do Povo Brasileiro. 4a edição. Rio de Janeiro, José Olympio. 


\section{Christian Edward Cyril Lynch}

(1974), Instituições Políticas Brasileiras. Volume II: Metodologia do direito público (os problemas brasileiros de ciência política). 3a edição. Rio de Janeiro, Distribuidora Record.

VITA, Luís Washington. (1965), Alberto Sales: Ideólogo da República. São Paulo, Companhia Editora Nacional.

WEFFORT, Francisco. (2006), Formação do Pensamento Político Brasileiro. Idéias e Personagens. São Paulo, Ática.

ZEA, Leopoldo. (1956), Esquema para una Historia de las Ideas en Iberoamerica. México, Universidad Nacional Autónoma.

. (1983), "La Historia en la Conciencia Americana", in Luis José Gonzales Alvarez, (org.), Temas de Filosofia de la Historia Latinoamericana. Bogotá, Editorial El Buho. 


\section{ABSTRACT \\ Why Thought and not Theory? The Brazilian Political and Social Imagination and the Spectrum of Peripheral Condition (1880-1970)}

Why do we refer to Brazilian political reflection as Thought rather than theory? The hypothesis I intend to explore here is that in Brazil, the main reason for the term "thought" to refer to the country's intellectual products lies in the fact that the elites have always considered such products more or less inferior to those developed in Europe and the United States, due to their own more general perception of Brazil's peripheral status. To frame this question, I will discuss the terminological issue of "theory" and "thought" in the field of political science. Next, I will examine how some leading Brazilian scholars assess the country's place in the world and the quality of its intellectual products, especially those of a social and political nature. This analysis will be divided into two periods, the first pertaining to the predominance of the cosmopolitan cultural paradigm from the late $19^{\text {th }}$ century to the $1920 \mathrm{~s}$, and the second with the nationalist cultural paradigm, lasting nearly until the late $20^{\text {th }}$ century.

Key words: periphery; philosophy of history; Brazilian political and social thought

\section{RÉSUMÉ}

Pourquoi Pensée et non Théorie? L'Imagination Politique et Social Brésilienne et le Spectre de la Condition Périphérique

Pourquoi désigne-t-on la réflexion politique brésilienne par pensée et non pas théorie? On formule ici l'hypothèse que la raison pour laquelle, au Brésil, il est usuel de nommer "pensée" ses produits intellectuels, vient du fait que les élites d'ici les ont toujours considérés comme inférieurs à ceux développés en Europe et aux États Unis, en raison d'une large perception du caractère périphérique de leur pays. En contexte à cette hypothèse, on examinera l'écart terminologique entre "théorie" et "pensée" dans le cadre de la science politique. Ensuite, on verra comment certains de nos principaux interprètes ont évalué la position du Brésil dans le monde ainsi que la qualité de ses produits intellectuels, surtout ceux de nature sociale et politique. Cet examen comprend deux moments: le premier concernant la période où a prévalu le paradigme culturel cosmopolite, depuis la fin du XIX ${ }^{\mathrm{e}}$ siècle jusqu'aux années 1920, et le second, pratiquement jusqu'à la fin du XXe siècle, où l'accent a été mis sur le paradigme culturel nationaliste.

Mots-clés: périphérie; philosophie de l'histoire; pensée politique et sociale brésilienne 